\title{
Zinc Complexes Derived from 5-Bromo-2-(((2-isopropylamino)ethyl)imino)methyl)phenol: Microwave-Assisted Synthesis, Characterization, Crystal Structures and Antibacterial Activities
}

\author{
Wei-Guang Zhang ${ }^{1, *}$ and Ji-Hong Liang ${ }^{2}$ \\ ${ }^{1}$ College of Chemistry and Chemical Engineering, Qiqihar University, Qiqihar 161006, P. R. China \\ ${ }^{2}$ Library, Qiqihar University, Qiqihar 161006, P. R. China \\ *Corresponding author: E-mail: zhangweiguang1230@163.com
}

Received: 04-22-2021

\begin{abstract}
Three new zinc complexes $\left[\mathrm{Zn}_{3} \mathrm{~L}_{2}\left(\mu_{2}-\eta^{1}: \eta^{1}-\mathrm{CH}_{3} \mathrm{COO}\right)_{2}\left(\mu_{2}-\eta^{2}: \eta^{0}-\mathrm{CH}_{3} \mathrm{COO}\right)_{2}\right](\mathbf{1}),\left[\mathrm{ZnCl}_{2}(\mathrm{HL})\right](\mathbf{2})$ and $\left[\mathrm{ZnBr}_{2}(\mathrm{HL})\right](\mathbf{3})$, where $\mathrm{L}=5$-bromo-2-(((2-isopropylamino)ethyl)imino)methyl)phenolate, $\mathrm{HL}=5$-bromo-2-(((2-isopropylammonio) ethyl)imino)methyl)phenolate, have been synthesized under microwave irradiation. The complexes were characterized by elemental analyses, IR, UV-Vis spectra, molar conductivity, and single crystal X-ray diffraction. X-ray analysis revealed that the $\mathrm{Zn}$ atoms in complex $\mathbf{1}$ are in square pyramidal and octahedral coordination, and those in complexes 2 and 3 are in tetrahedral coordination. The molecules of the complexes are linked through hydrogen bonds and $\pi \cdots \pi$ interactions. In order to evaluate the biological activity of the complexes, in vitro antibacterial against Staphylococcus aureus, Bacillus subtilis, Escherichia coli and Pseudomonas aeruginosa was assayed.
\end{abstract}

Keywords: Schiff base; zinc complex; X-ray diffraction; antibacterial activity

\section{Introduction}

In the past few years, microwave-assisted preparation has attracted enormous interest in the fields of coordination chemistry and inorganic synthesis. ${ }^{1}$ Microwave irradiation can accelerate many chemical reactions. This method of synthesis has also advantages in providing a clean, cheap and easy handling heating way, which achieves higher yields with less reaction time. ${ }^{2}$ Penicillins and cephalosporins disrupt the formation of the bacterial cell wall, but many bacteria strains have developed resistance to them. ${ }^{3}$ Thus, to explore new antibacterial drugs is a hot topic in chemical and biological areas. ${ }^{4}$ Schiff bases have been known for a long time for their interesting biological activities and coordination capability for metal ions. ${ }^{5}$ When bioorganic molecules or drugs are bound to metal ions, there is drastic change in their biomimetic properties, therapeutic effects and pharmacological properties. Zinc complexes are found to be antitumor active, catalytic active, antimicrobial and cytotoxic. ${ }^{6}$ In this study, the synthesis, characterization and antibacterial properties of three new zinc complexes $\left[\mathrm{Zn}_{3} \mathrm{~L}_{2}\left(\mu_{2}-\eta^{1}: \eta^{1}-\mathrm{CH}_{3} \mathrm{COO}\right)_{2}\left(\mu_{2^{-}}\right.\right.$ $\left.\left.\eta^{2}: \eta^{0}-\mathrm{CH}_{3} \mathrm{COO}\right)_{2}\right](\mathbf{1}),\left[\mathrm{ZnCl}_{2}(\mathrm{HL})\right](2)$ and $\left[\mathrm{ZnBr}_{2}(\mathrm{HL})\right]$ (3), where $\mathrm{L}=5$-bromo-2-(((2-isopropylamino)ethyl)imino)methyl)phenolate, $\mathrm{HL}=5$-bromo-2-((2-isopropylammonio)ethyl)imino)methyl)phenolate, are presented.

\section{Experimental}

\section{1. Materials and Physical Methods}

All the starting materials and solvents used in the present investigation were of analytical grade and used without further purification. 4-Bromosalicylaldehyde and $\mathrm{N}$-isopropylethane-1,2-diamine were purchased from TCI. WX-4000 microwave digestion system was used in microwave synthesis. Elemental analyses were performed on a Perkin-Elmer 2400 Elemental Analyzer. IR spectra were recorded as $\mathrm{KBr}$ pellets on a Bio-Rad FTS $135 \mathrm{spec}-$ trophotometer in the range of $4000-400 \mathrm{~cm}^{-1}$. Electronic spectra were recorded on a Lambda 35 spectrometer. Conductivities of $10^{-3} \mathrm{M}$ solutions in acetonitrile were measured on a DDS-11A conductivity meter. Single crystal 
X-ray diffraction was carried out with a Bruker Smart 1000 CCD diffractometer.

\section{2. Synthesis of Complex 1}

4-Bromosalicylaldehyde $(0.20 \mathrm{~g}, 1.0 \mathrm{mmol}), \mathrm{N}$-isopropylethane-1,2-diamine $(0.10 \mathrm{~g}, 1.0 \mathrm{mmol})$, zinc acetate dihydrate $(0.22 \mathrm{~g}, 1.0 \mathrm{mmol})$ and methanol $(20 \mathrm{~mL})$ were placed in a $30-\mathrm{mL}$ Teflon-lined autoclave, which was then inserted into the cavity of a microwave reactor. The reaction mixture was maintained at $350 \mathrm{~K}$ and $200 \mathrm{~W}$ for $10 \mathrm{~min}$. Then natural cooling was followed for about $1 \mathrm{~h}$. The resulting solution was then filtered and allowed to evaporate slowly at room temperature for 5 days. The diffraction quality colorless single crystals were collected by filtration and washed with methanol. The yield was $0.22 \mathrm{~g}(66 \%)$. Anal. Calcd. for $\mathrm{C}_{32} \mathrm{H}-$ ${ }_{44} \mathrm{Br}_{2} \mathrm{~N}_{4} \mathrm{O}_{10} \mathrm{Zn}_{3}$ (\%): C, 38.41; H, 4.43; N, 5.60. Found (\%): C, 38.27; H, 4.52; N, 5.71. IR data $\left(\mathrm{KBr}, \mathrm{cm}^{-1}\right): 3093,1648,1581$, $1523,1459,1431,1401,1370,1318,1292,1252,1230,1188$, $1161,1133,1075,1061,956,926,911,868,788,775,670$, $615,545,470$. UV-Vis data in methanol $\left[\lambda_{\max }(\mathrm{nm}), \varepsilon\right.$ $\left.\left(\mathrm{L} \cdot \mathrm{mol}^{-1} \cdot \mathrm{cm}^{-1}\right)\right]: 239,15370 ; 273,9260 ; 340,4535$.

\section{3. Synthesis of Complex 2}

4-Bromosalicylaldehyde $(0.20 \mathrm{~g}, 1.0 \mathrm{mmol}), \mathrm{N}$-isopropylethane-1,2-diamine $(0.10 \mathrm{~g}, 1.0 \mathrm{mmol})$, zinc chloride $(0.14 \mathrm{~g}, 1.0 \mathrm{mmol})$ and methanol $(20 \mathrm{~mL})$ were placed in a
30-mL Teflon-lined autoclave, which was then inserted into the cavity of a microwave reactor. The reaction mixture was maintained at $350 \mathrm{~K}$ and $200 \mathrm{~W}$ for $10 \mathrm{~min}$. Then natural cooling was followed for about $1 \mathrm{~h}$. The resulting solution was then filtered and allowed to evaporate slowly at room temperature for 8 days. The diffraction quality colorless single crystals were collected by filtration and washed with methanol. The yield was $0.26 \mathrm{~g}$ (62\%). Anal. Calcd. for $\mathrm{C}_{12} \mathrm{H}_{17} \mathrm{BrCl}_{2} \mathrm{~N}_{2} \mathrm{OZn}(\%): \mathrm{C}, 34.20 ; \mathrm{H}, 4.07 ; \mathrm{N}, 6.65$. Found (\%): C, 34.33; H, 4.15; N, 6.56. IR data $\left(\mathrm{KBr}, \mathrm{cm}^{-1}\right)$ : 3105, $1634,1585,1576,1525,1468,1447,1401,1344,1282,1237$, $1182,1158,1131,1071,1039,960,913,847,785,608,583$, 532,465 . UV-Vis data in methanol $\left[\lambda_{\max }(\mathrm{nm}), \varepsilon\left(\mathrm{L} \cdot \mathrm{mol}^{-1}\right.\right.$. $\left.\mathrm{cm}^{-1}\right)$ ]: 227, 16250; 246, 17100; 273, 9250; 365, 4520.

\section{4. Synthesis of Complex 3}

4-Bromosalicylaldehyde $(0.20 \mathrm{~g}, 1.0 \mathrm{mmol}), \mathrm{N}$-isopropylethane-1,2-diamine $(0.10 \mathrm{~g}, 1.0 \mathrm{mmol})$, zinc bromide $(0.23 \mathrm{~g}, 1.0 \mathrm{mmol})$ and methanol $(20 \mathrm{~mL})$ were placed in a $30-\mathrm{mL}$ Teflon-lined autoclave, which was then inserted into the cavity of a microwave reactor. The reaction mixture was maintained at $350 \mathrm{~K}$ and $200 \mathrm{~W}$ for 10 $\mathrm{min}$. Then natural cooling was followed for about $1 \mathrm{~h}$. The resulting solution was then filtered and allowed to evaporate slowly at room temperature for 6 days. The diffraction quality colorless single crystals were collected by filtration and washed with methanol. The yield was $0.26 \mathrm{~g}(62 \%)$.

Table 1. Crystallographic data for the complexes

\begin{tabular}{|c|c|c|c|}
\hline Complex & 1 & 2 & 3 \\
\hline Formula & $\mathrm{C}_{32} \mathrm{H}_{44} \mathrm{Br}_{2} \mathrm{~N}_{4} \mathrm{O}_{10} \mathrm{Zn}_{3}$ & $\mathrm{C}_{12} \mathrm{H}_{17} \mathrm{BrCl}_{2} \mathrm{~N}_{2} \mathrm{OZn}$ & $\mathrm{C}_{12} \mathrm{H}_{17} \mathrm{Br}_{3} \mathrm{~N}_{2} \mathrm{OZn}$ \\
\hline Formula weight & 1000.64 & 421.46 & 510.38 \\
\hline Crystal system & Triclinic & Monoclinic & Monoclinic \\
\hline Space group & $P-1$ & $P 2_{1} / n$ & $P 2_{1} / n$ \\
\hline$a(\AA)$ & $8.6285(12)$ & $6.2574(16)$ & $6.3937(8)$ \\
\hline$b(\AA)$ & $11.3804(13)$ & $11.6604(17)$ & $11.9598(12)$ \\
\hline$c(\AA)$ & $19.8737(15)$ & $22.1717(19)$ & $21.9993(13)$ \\
\hline$\alpha\left({ }^{\circ}\right)$ & $86.433(1)$ & 90 & 90 \\
\hline$\beta\left({ }^{\circ}\right)$ & $89.601(1)$ & $94.109(1)$ & $95.186(1)$ \\
\hline$\gamma\left({ }^{\circ}\right)$ & $84.145(1)$ & 90 & 90 \\
\hline$V\left(\AA^{3}\right)$ & $1937.6(4)$ & $1613.6(5)$ & $1675.3(3)$ \\
\hline$\lambda(\AA)$ & 0.71073 & 0.71073 & 0.71073 \\
\hline$\rho_{\text {calcd }}\left(\mathrm{g} \mathrm{cm}^{-3}\right)$ & 1.715 & 1.735 & 2.023 \\
\hline$Z$ & 2 & 4 & 4 \\
\hline$\mu\left(\mathrm{mm}^{-1}\right)$ & 3.962 & 4.322 & 8.614 \\
\hline$\theta$ ranges $\left({ }^{\circ}\right)$ & $1.80-25.50$ & $1.84-25.50$ & $1.86-25.50$ \\
\hline Reflections collected & 10470 & 8194 & 8790 \\
\hline Independent reflections & 7180 & 2999 & 3120 \\
\hline \multicolumn{4}{|l|}{ Observed reflections } \\
\hline$(I \geq 2 \sigma(I))$ & 4961 & 2398 & 2409 \\
\hline Restraints & 26 & 0 & 0 \\
\hline Parameters & 515 & 173 & 174 \\
\hline Goodness-of-fit on $F^{2}$ & 1.022 & 1.167 & 1.040 \\
\hline Final $R$ indices $[I \geq 2 \sigma(I)]$ & $0.0405,0.0824$ & $0.0684,0.1780$ & $0.0332,0.0724$ \\
\hline$R$ indices (all data) & $0.0731,0.0929$ & $0.0813,0.1828$ & $0.0513,0.0781$ \\
\hline
\end{tabular}


Anal. Calcd. for $\mathrm{C}_{12} \mathrm{H}_{17} \mathrm{Br}_{3} \mathrm{~N}_{2} \mathrm{OZn}(\%)$ : C, 28.24; $\mathrm{H}, 3.36$; $\mathrm{N}, 5.49$. Found (\%): C, 28.33; H, 3.29; N, 5.61. IR data $\left(\mathrm{KBr}, \mathrm{cm}^{-1}\right): 3096,1633,1585,1575,1521,1466,1446$, $1401,1344,1280,1238,1182,1152,1131,1070,1037,958$, $913,847,785,608,581,532,465$. UV-Vis data in methanol $\left[\lambda_{\max }(\mathrm{nm}), \varepsilon\left(\mathrm{L} \cdot \mathrm{mol}^{-1} \cdot \mathrm{cm}^{-1}\right)\right]: 227,16250 ; 246,17100 ; 273$, 9250; 365, 4520 .

\section{5. X-Ray Structure Determination}

Single-crystals X-ray diffraction analyses of the complexes were carried out on a Bruker Smart 1000 CCD diffractometer equipped with a graphite monochromated Mo Ka radiation $(\lambda=0.71073 \AA$ ) at 298(2) K. Raw frame data were integrated with the SAINT program. ${ }^{7}$ The structures were solved by direct methods and refined by full-matrix least-squares on $F^{2}$ using SHELXL. ${ }^{8}$ An empirical absorption correction was applied with the program SADABS. ${ }^{9}$ All non-hydrogen atoms were refined anisotropically. The N2-C26-C27-C28 moiety of complex 1 is disordered over two sites, with occupancies of $0.44(2)$ and $0.56(2)$. The N3-C8-C9-N4 moiety of complex 1 is disordered over two sites, with occupancies of $0.61(2)$ and 0.39(2). Molecular graphics software used was ORTEP

Table 2. Selected bond distances $(\AA)$ and bond angles $\left({ }^{\circ}\right)$ for the complexes

\begin{tabular}{|c|c|c|c|}
\hline \multicolumn{4}{|c|}{1} \\
\hline $\mathrm{Zn} 1-\mathrm{O} 1$ & $2.117(3)$ & $\mathrm{Zn} 1-\mathrm{O} 3$ & $1.984(3)$ \\
\hline $\mathrm{Zn} 1-\mathrm{O} 4$ & $2.020(3)$ & $\mathrm{Zn} 1-\mathrm{N} 3$ & $2.014(4)$ \\
\hline $\mathrm{Zn} 1-\mathrm{N} 4$ & $2.175(4)$ & $\mathrm{Zn} 2-\mathrm{O} 2$ & $2.047(3)$ \\
\hline $\mathrm{Zn} 2-\mathrm{O} 1$ & $2.113(3)$ & $\mathrm{Zn} 2-\mathrm{O} 4$ & $2.155(3)$ \\
\hline $\mathrm{Zn3-O7}$ & $1.990(3)$ & $\mathrm{Zn3-N1}$ & $2.031(4)$ \\
\hline $\mathrm{Zn3-O6}$ & $2.095(3)$ & $\mathrm{Zn3-O9}$ & $2.123(3)$ \\
\hline $\mathrm{Zn} 3-\mathrm{N} 2$ & $2.176(4)$ & $\mathrm{Zn} 4-\mathrm{O} 8$ & $2.050(3)$ \\
\hline $\mathrm{Zn} 4-\mathrm{O} 6$ & $2.107(3)$ & $\mathrm{Zn} 4-\mathrm{O} 9$ & $2.144(3)$ \\
\hline O3-Zn1-N3 & $115.48(17)$ & $\mathrm{O} 3-\mathrm{Zn} 1-\mathrm{O} 4$ & $103.27(12)$ \\
\hline N3-Zn1-O4 & $140.15(16)$ & $\mathrm{O} 3-\mathrm{Zn} 1-\mathrm{O} 1$ & $94.56(12)$ \\
\hline N3-Zn1-O1 & $86.40(13)$ & $\mathrm{O} 4-\mathrm{Zn} 1-\mathrm{O} 1$ & $81.44(10)$ \\
\hline $\mathrm{O} 3-\mathrm{Zn} 1-\mathrm{N} 4$ & $97.54(14)$ & $\mathrm{N} 3-\mathrm{Zn} 1-\mathrm{N} 4$ & $82.07(15)$ \\
\hline $\mathrm{O} 4-\mathrm{Zn} 1-\mathrm{N} 4$ & $102.48(14)$ & $\mathrm{O} 1-\mathrm{Zn} 1-\mathrm{N} 4$ & $166.00(13)$ \\
\hline $\mathrm{O} 2-\mathrm{Zn} 2-\mathrm{O} 2 \mathrm{~A}$ & 180 & $\mathrm{O} 2-\mathrm{Zn} 2-\mathrm{O} 1 \mathrm{~A}$ & $89.96(11)$ \\
\hline $\mathrm{O} 2-\mathrm{Zn} 2-\mathrm{O} 1$ & $90.04(11)$ & $\mathrm{O} 1-\mathrm{Zn} 2-\mathrm{O} 1 \mathrm{~A}$ & 180 \\
\hline $\mathrm{O} 2-\mathrm{Zn} 2-\mathrm{O} 4 \mathrm{~A}$ & $90.27(11)$ & $\mathrm{O} 1-\mathrm{Zn} 2-\mathrm{O} 4 \mathrm{~A}$ & $101.49(10)$ \\
\hline $\mathrm{O} 2-\mathrm{Zn} 2-\mathrm{O} 4$ & $89.73(11)$ & $\mathrm{O} 1-\mathrm{Zn} 2-\mathrm{O} 4$ & $78.51(10)$ \\
\hline $\mathrm{O} 4-\mathrm{Zn} 2-\mathrm{O} 4 \mathrm{~A}$ & 180 & $\mathrm{O} 7-\mathrm{Zn} 3-\mathrm{N} 1$ & $110.33(16)$ \\
\hline O7-Zn3-O6 & $96.20(12)$ & $\mathrm{N} 1-\mathrm{Zn} 3-\mathrm{O} 6$ & $86.91(14)$ \\
\hline O7-Zn3-O9 & $96.93(12)$ & $\mathrm{N} 1-\mathrm{Zn} 3-\mathrm{O} 9$ & $150.95(15)$ \\
\hline O6-Zn3-O9 & $80.15(11)$ & $\mathrm{O} 7-\mathrm{Zn} 3-\mathrm{N} 2$ & $93.5(2)$ \\
\hline $\mathrm{N} 1-\mathrm{Zn} 3-\mathrm{N} 2$ & $81.08(18)$ & O6-Zn3-N2 & $166.63(15)$ \\
\hline O9-Zn3-N2 & $107.9(2)$ & $\mathrm{O} 8-\mathrm{Zn} 4-\mathrm{O} 8 \mathrm{~B}$ & 180 \\
\hline O8-Zn4-O6B & $89.91(12)$ & O8-Zn4-O6 & $89.98(11)$ \\
\hline O6-Zn4-O6B & 180 & O6-Zn4-O9B & $100.61(11)$ \\
\hline O8-Zn4-O9B & $90.72(11)$ & O8-Zn4-O9 & $90.72(11)$ \\
\hline O6-Zn4-O9 & $79.39(12)$ & O9-Zn4-O9B & 180 \\
\hline \multicolumn{4}{|c|}{ Symmetry codes: A) $2-x, 1-y, 1-z$; B) $1-x, 1-y,-z$} \\
\hline \multicolumn{4}{|c|}{2} \\
\hline $\mathrm{Zn} 1-\mathrm{Cl} 1$ & $2.246(3)$ & $\mathrm{Zn} 1-\mathrm{Cl} 2$ & $2.228(3)$ \\
\hline $\mathrm{Zn} 1-\mathrm{O} 1$ & $1.936(6)$ & $\mathrm{Zn1-N1}$ & $2.004(7)$ \\
\hline $\mathrm{O} 1-\mathrm{Zn} 1-\mathrm{N} 1$ & $97.1(3)$ & $\mathrm{O} 1-\mathrm{Zn} 1-\mathrm{Cl} 2$ & $108.1(2)$ \\
\hline $\mathrm{N} 1-\mathrm{Zn} 1-\mathrm{Cl} 2$ & $112.6(2)$ & $\mathrm{O} 1-\mathrm{Zn} 1-\mathrm{Cl} 1$ & $111.4(2)$ \\
\hline N1-Zn1-Cl1 & $109.9(2)$ & $\mathrm{Cl} 2-\mathrm{Zn} 1-\mathrm{Cl} 1$ & $116.12(11)$ \\
\hline \multicolumn{4}{|c|}{3} \\
\hline $\mathrm{Zn} 1-\mathrm{Br} 1$ & $2.3658(6)$ & $\mathrm{Zn} 1-\mathrm{Br} 2$ & $2.3784(7)$ \\
\hline $\mathrm{Zn} 1-\mathrm{O} 1$ & $1.939(3)$ & Zn1-N1 & $2.000(3)$ \\
\hline $\mathrm{O} 1-\mathrm{Zn} 1-\mathrm{N} 1$ & $97.55(12)$ & $\mathrm{O} 1-\mathrm{Zn} 1-\mathrm{Br} 1$ & $109.65(8)$ \\
\hline $\mathrm{N} 1-\mathrm{Zn} 1-\mathrm{Br} 1$ & $110.19(9)$ & $\mathrm{O} 1-\mathrm{Zn} 1-\mathrm{Br} 2$ & $111.09(9)$ \\
\hline $\mathrm{N} 1-\mathrm{Zn} 1-\mathrm{Br} 2$ & $111.26(9)$ & $\mathrm{Br} 1-\mathrm{Zn} 1-\mathrm{Br} 2$ & $115.62(3)$ \\
\hline
\end{tabular}


III. ${ }^{10}$ The crystal data for the complexes are listed in Table 1. Selected bond lengths and angles for the complexes are listed in Table 2.

\section{6. Antibacterial Activity}

The free Schiff base and the zinc complexes were screened in vitro for their antibacterial property against two Gram-positive (Staphylococcus aureus MTCC 96, Bacillus subtilis MTCC 121) and two Gram-negative (Escherichia coli MTCC 1652, Pseudomonas aeruginosa MTCC 741) bacterial strains by agar well diffusion method. ${ }^{11}$ DMSO was used as a negative control, and Ciprofloxacin was used as positive control.

\section{7. Determination of Minimum Inhibitory Concentration (MIC)}

MIC of the compounds against bacterial strains was tested through a modified agar well diffusion method. ${ }^{12} \mathrm{~A}$ twofold serial dilution of each compound was prepared by first reconstituting the compound in DMSO followed by dilution in sterile distilled water to achieve a decreasing concentration range $256 \mu \mathrm{M}$. A $100 \mu \mathrm{L}$ volume of each dilution was introduced into wells in the agar plates already seeded with $100 \mu \mathrm{L}$ of standardized inoculums $\left(10^{6} \mathrm{cfu}\right.$ $\mathrm{mL}^{-1}$ ) of the test microbial strain. All test plates were incubated aerobically at $37^{\circ} \mathrm{C}$ for $24 \mathrm{~h}$ and observed for the inhibition zones.

\section{Results and Discussion}

\section{1. Chemistry}

Reaction of the newly formed Schiff base HL with zinc acetate, zinc chloride and zinc bromide, respectively, afforded the trinuclear zinc complex 1 and mononuclear zinc complexes $\mathbf{2}$ and $\mathbf{3}$ (Scheme 1). The poor conductivity of complexes 1-3 $\left(20-40 \Omega^{-1} \mathrm{~cm}^{2} \mathrm{~mol}^{-1}\right)$ indicates they are non-electrolytes in solution. ${ }^{13}$

\section{2. Infrared and Electronic Spectra}

In the infrared spectra of the complexes, the weak absorptions in the range $3093-3177 \mathrm{~cm}^{-1}$ are assigned to the N-H vibrations of the Schiff base ligands. The characteristic imine stretching is observed at $1633-1648 \mathrm{~cm}^{-1}$ as strong signal. ${ }^{14}$ The asymmetric and symmetric stretching vibrations of the acetate groups in $\mathbf{1}$ appear at 1581 and $1431 \mathrm{~cm}^{-1}$, respectively. The difference between $v_{\text {asym }}(\mathrm{COO})$ and $v_{\text {sym }}(\mathrm{COO})\left(\Delta v=150 \mathrm{~cm}^{-1}\right)$, which is smaller than $164 \mathrm{~cm}^{-1}$ observed in ionic acetate, reflects the bidentate bridging coordination mode. ${ }^{15}$ The Schiff base ligands coordination is substantiated by the phenolic $\mathrm{C}-\mathrm{O}$ stretching bands at $1175-1188 \mathrm{~cm}^{-1}$ in the complexes. ${ }^{16}$ Coordination of the Schiff bases is further confirmed by the appearance of weak bands in the low wave numbers $400-600 \mathrm{~cm}^{-1}$, corresponding to $v(\mathrm{M}-\mathrm{N})$ and $v(\mathrm{M}-\mathrm{O}){ }^{17}$

In the UV-Vis spectra of the complexes, the bands at $225-246 \mathrm{~nm}$ and $257-273 \mathrm{~nm}$ are attributed to the $\pi-\pi^{*}$<smiles>CC(C)NCC/N=C/c1ccc(Br)cc1O</smiles>

HL<smiles>[Y4][Y4]([H])([H])[H]</smiles>

Scheme 1. The synthetic procedure for the Schiff base and the complexes. 
and $n-\pi^{*}$ transitions. ${ }^{18}$ The bands at $340-380 \mathrm{~nm}$ can be attributed to the ligand to metal charge transfer transition (LMCT). ${ }^{19}$

\section{3. Structure Description of Complex 1}

The molecular structure of the acetate and phenolate bridged trinuclear zinc complex is shown in Fig. 1. There are two halves of coordination molecules in the asymmetric unit of the complex. Each molecule possesses crystallographic inversion center symmetry, with the center located at $\mathrm{Zn} 2$ atom. The outer and inner $\mathrm{Zn}$ atoms are linked through three kinds of bridging groups, including phenolate oxygen, $\mu_{2}-\eta^{1}: \eta^{1}$-acetate, and $\mu_{2}-\eta^{2}: \eta^{0}$-acetate. The distance between the $\mathrm{Zn}$ atoms is 3.064(1) $\AA$. The outer $\mathrm{Zn}$ atom is coordinated in square pyramidal geometry, as evidenced by the $\tau$ value. ${ }^{20}$ The

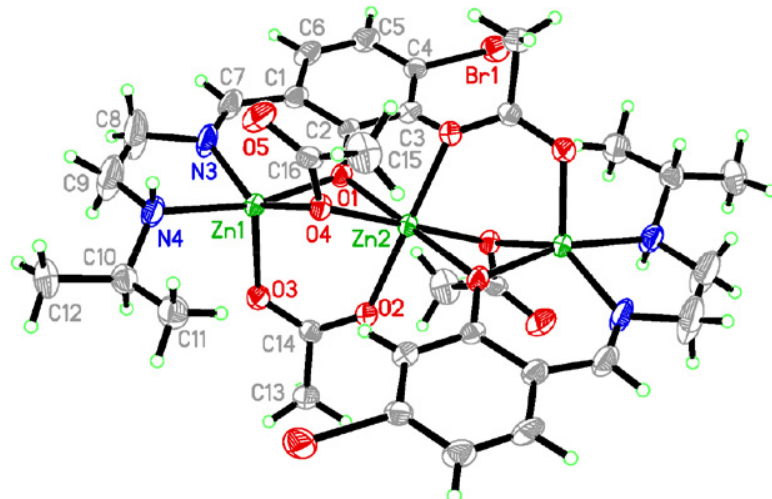

Fig. 1. Molecular structure of complex 1. Unlabeled atoms are related to the symmetry operation $2-x, 1-y, 1-z$. Displacement ellipsoids are drawn at the $30 \%$ probability level. basal plane is defined by the phenolate oxygen, imino and amino nitrogen of the Schiff base ligand, and one $\mathrm{O}$ atom of the $\mu_{2}-\eta^{2}: \eta^{0}$-acetate ligand. The apical position is occupied by one $\mathrm{O}$ atom of the $\mu_{2}-\eta^{1}: \eta^{1}$-acetate ligand. The $\mathrm{Zn}$ atoms deviate from the corresponding basal planes by 0.440 (3) $\AA$ for Zn1 and 0.320(3) A for Zn3. The square pyramidal coordination is distorted from ideal model, as evidenced by the bond angles. The cis and trans angles in the basal planes are in the ranges of $81.48(11)$ $102.49(15)^{\circ}$ and $140.15(18)-166.06(14)^{\circ}$ for $\mathrm{Zn} 1$, and $80.15(12)-107.9(2)^{\circ}$ and $151.02(16)-166.59(16)^{\circ}$ for $\mathrm{Zn} 3$, respectively. The bond angles among the apical and basal donor atoms are in the ranges of 94.58(13)$115.49(18)^{\circ}$ for $\mathrm{Zn} 1$ and 93.4(2)-110.28(17) ${ }^{\circ}$ for $\mathrm{Zn3}$. The inner $\mathrm{Zn}$ atom is coordinated in octahedral geometry. The equatorial plane is defined by two phenolate oxygen from two Schiff base ligands, and two $\mathrm{O}$ atoms from two $\mu_{2}-\eta^{2}: \eta^{0}$-acetate ligands. The axial positions are occupied by two $\mathrm{O}$ atoms from two $\mu_{2}-\eta^{1}: \eta^{1}$-acetate ligands. The octahedral coordination is distorted from ideal model, as evidenced by the bond angles. The cis and trans angles in the equatorial planes are in the ranges of $78.48(11)-101.52(11)^{\circ}$ and $101.52(11)^{\circ}$ for $\mathrm{Zn} 2$, and $79.37(12)-100.63(12)^{\circ}$ and $180.00(16)^{\circ}$ for $\mathrm{Zn} 4$, respectively. The bond angles among the apical and basal donor atoms are in the ranges of $89.78(12)-90.22(12)^{\circ}$ for $\mathrm{Zn} 2$ and $89.22(12)-90.78(12)^{\circ}$ for $\mathrm{Zn} 4$. The $\mathrm{Zn}-\mathrm{O}$ and $\mathrm{Zn}-\mathrm{N}$ bond lengths are comparable to those observed in Schiff base zinc complexes with acetate ligands. ${ }^{21}$

In the crystal structure of the complex, the molecules are linked through $\mathrm{C}-\mathrm{H}$... O hydrogen bonds ( $\mathrm{Ta}$ ble 3 ), to form one-dimensional chains along the $c$ axis (Fig. 2).

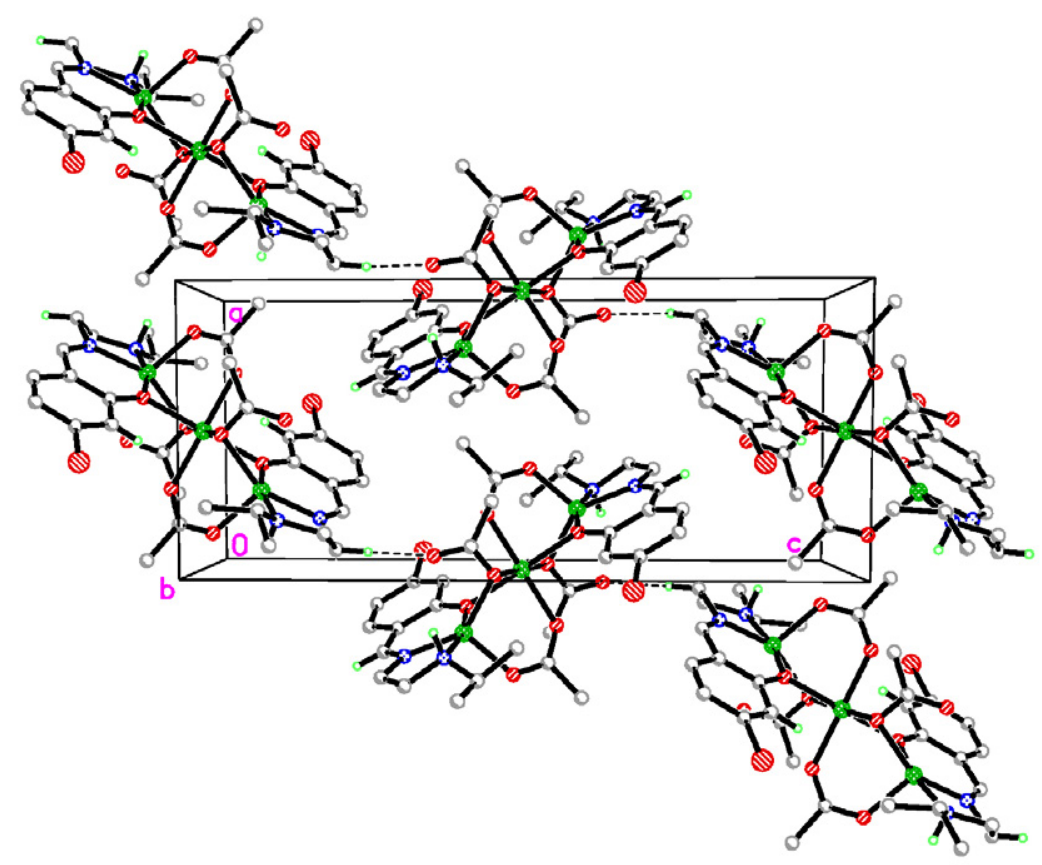

Fig. 2. Molecular packing structure of complex 1. Hydrogen bonds are drawn as dashed lines. 


\section{4. Structure Description of Complexes 2 and 3}

Molecular structures of complexes $\mathbf{2}$ and $\mathbf{3}$ are shown in Figs. 3 and 4, respectively. The complexes are isostruc-

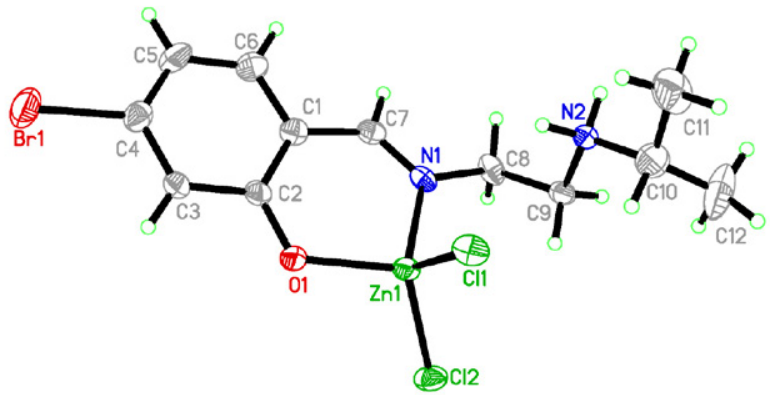

Fig. 3. Molecular structure of complex 2. Displacement ellipsoids are drawn at the $30 \%$ probability level.

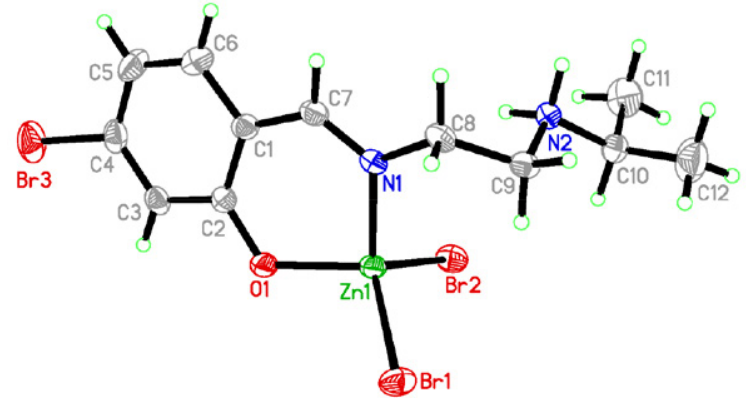

Fig. 4. Molecular structure of complex 3. Displacement ellipsoids are drawn at the $30 \%$ probability level. tural mononuclear zinc compounds. The $\mathrm{Zn}$ atom in each complex is coordinated by the phenolate oxygen and imino nitrogen of the Schiff base ligand and two halide atoms, viz. $\mathrm{Cl}$ for $\mathbf{2}$ and $\mathrm{Br}$ for $\mathbf{3}$, forming tetrahedral geometry. The tetrahedral coordination is distorted from ideal model, as evidenced by the bond angles. The coordinate bond angles in complexes 2 and 3 are in the ranges of 97.1(3)-

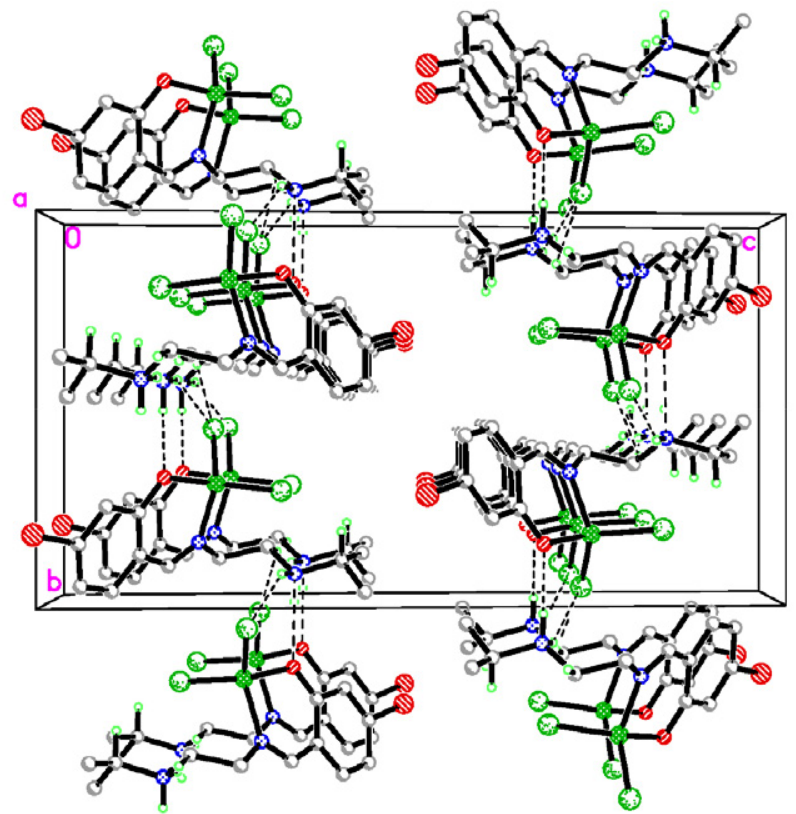

Fig. 5. Molecular packing structure of complex 2. Hydrogen bonds are drawn as dashed lines.

Table 3. Hydrogen bond distances $(\AA)$ and bond angles $\left({ }^{\circ}\right)$ for the complexes

\begin{tabular}{|c|c|c|c|c|}
\hline$D-\mathrm{H} \cdots A$ & $d(D-H)$ & $d(\mathbf{H} \cdots A)$ & $d(\mathrm{D} \cdots A)$ & Angle $(D-H \cdots A)$ \\
\hline \multicolumn{5}{|c|}{1} \\
\hline N4-H4A $\cdots \mathrm{O} 5$ & 0.91 & 2.45 & $3.055(6)$ & $124(5)$ \\
\hline $\mathrm{N} 4-\mathrm{H} 4 \mathrm{~A} \cdots \mathrm{Br} 1^{\# 1}$ & 0.91 & 3.00 & $3.863(5)$ & $160(5)$ \\
\hline $\mathrm{C} 7-\mathrm{H} 7 \cdots \mathrm{O} 10^{\# 2}$ & 0.93 & 2.60 & $3.445(5)$ & $151(5)$ \\
\hline C19-H19 ...O9 & 0.93 & 2.51 & $3.285(5)$ & $141(5)$ \\
\hline $\mathrm{C} 24-\mathrm{H} 24 \mathrm{~B} \cdots \mathrm{O} 5^{\# 4}$ & 0.97 & 2.52 & $3.292(5)$ & $136(5)$ \\
\hline \multicolumn{5}{|c|}{2} \\
\hline $\mathrm{N} 2-\mathrm{H} 2 \mathrm{~B} \cdots \mathrm{Cl} 1$ & 0.90 & 2.91 & $3.440(8)$ & $119(6)$ \\
\hline $\mathrm{N} 2-\mathrm{H} 2 \mathrm{~B} \cdots \mathrm{Cl} 2^{\# 5}$ & 0.90 & 2.57 & $3.316(8)$ & $141(6)$ \\
\hline $\mathrm{N} 2-\mathrm{H} 2 \mathrm{~A} \cdots \mathrm{O} 1^{\# 5}$ & 0.90 & 1.99 & $2.850(9)$ & $160(6)$ \\
\hline $\mathrm{C} 9-\mathrm{H} 9 \mathrm{~B} \cdots \mathrm{Cl} 2^{\# 6}$ & 0.97 & 2.72 & $3.463(8)$ & $133(6)$ \\
\hline $\mathrm{C} 10-\mathrm{H} 10 \ldots \mathrm{Cl} 1$ & 0.98 & 2.78 & $3.522(8)$ & $133(6)$ \\
\hline \multicolumn{5}{|c|}{3} \\
\hline $\mathrm{N} 2-\mathrm{H} 2 \mathrm{~B} \cdots \mathrm{Br} 2$ & 0.90 & 3.14 & $3.638(3)$ & $117(5)$ \\
\hline $\mathrm{N} 2-\mathrm{H} 2 \mathrm{~B} \cdots \mathrm{Br} 1^{\# 7}$ & 0.90 & 2.67 & $3.441(3)$ & $145(5)$ \\
\hline $\mathrm{N} 2-\mathrm{H} 2 \mathrm{~A} \cdots \mathrm{O} 1^{\mathrm{v} \# 7}$ & 0.90 & 2.04 & $2.886(4)$ & $157(5)$ \\
\hline C9-H9A $\cdots B r 1^{\# 8}$ & 0.97 & 2.84 & $3.561(4)$ & $132(5)$ \\
\hline $\mathrm{C} 10-\mathrm{H} 10 \cdots \mathrm{Br} 2$ & 0.98 & 2.92 & $3.660(4)$ & $133(5)$ \\
\hline
\end{tabular}

Symmetry codes: \#1: $x, 1+y, z ; \# 2: 1-x, 1-y, 1-z$; \#3: $1-x, 1-y,-z ; \# 4:-x, 1-y, 1-z$; \#5: $-x,-1-y$, $1-z ; \# 6: 5 / 2-x, 1 / 2+y, 1 / 2-z ; \# 7: 3 / 2-x, 1 / 2+y, 1 / 2-z ; \# 8: 5 / 2-x, 1 / 2+y, 1 / 2-z$. 


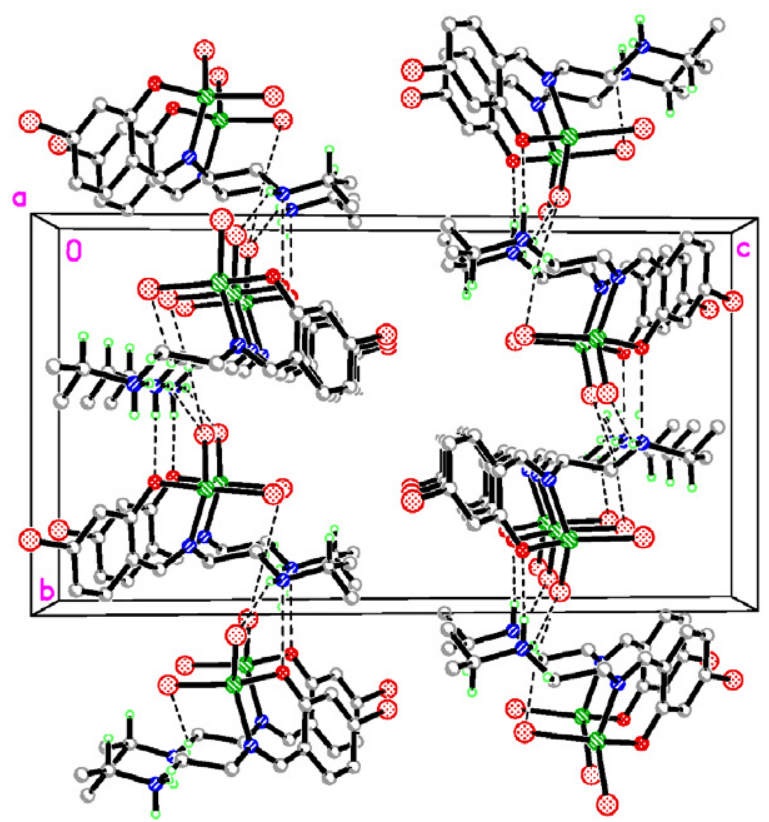

Fig. 6. Molecular packing structure of complex 3. Hydrogen bonds are drawn as dashed lines.

$116.12(11)^{\circ}$ and $97.55(12)-115.62(3)^{\circ}$, respectively. The $\mathrm{Zn}-\mathrm{O}, \mathrm{Zn}-\mathrm{N}, \mathrm{Zn}-\mathrm{Cl}$ and $\mathrm{Zn}-\mathrm{Br}$ bond lengths are comparable to those observed in Schiff base zinc complexes. ${ }^{22}$

As shown in Fig. 5, the molecules of complex 2 are linked through $\mathrm{N}-\mathrm{H} \cdots \mathrm{O}$ and $\mathrm{N}-\mathrm{H} \cdots \mathrm{Cl}$ hydrogen bonds (Table 3), to form one-dimensional chains along the $b$ axis. The chains are further linked through $\mathrm{C}-\mathrm{H}$... Cl hydrogen bonds (Table 3 ) along the $a$ axis to form two-dimensional sheets parallel to the $a b$ plane. As shown in Fig. 6, the molecules of complex 3 are linked through $\mathrm{N}-\mathrm{H}$... Br hydrogen bonds (Table 3 ), to form one-dimensional chains along the $b$ axis. The chains are further linked through $\mathrm{C}-\mathrm{H} \cdots \mathrm{Br}$ hydrogen bonds (Table 3 ) along the $a$ axis to form two-dimensional sheets parallel to the $a b$ plane.

\section{5. Antibacterial Activities}

The antibacterial results are listed in Tables 4 and 5. The studies suggested that the complexes showed somewhat enhanced antibacterial activities in comparison to the free Schiff base. Ciprofloxacin produced significantly sized inhibition zones against the tested bacteria, while DMSO, the negative control, produced no inhibitory effect against any of the tested organisms. The free Schiff base HL showed zones of inhibition in the range of 3.4-13.2 mm against the four bacteria. All the complexes have been observed to show increased zones of inhibition against the four bacterial strains as compared to the free Schiff base. The MIC results indicated that complexes $\mathbf{2}$ and $\mathbf{3}$ have similar activities against the bacterial strains, which are better than complex 1. Complex 1 have weak activities against the four bacteria. However, complexes $\mathbf{2}$ and $\mathbf{3}$ have strong activities against Bacillus subtilis and Escherichia coli, and weak activities against the remaining two bacteria. MIC results also revealed that the complexes are more effective against the antibacterial strains as compared to the free Schiff base. The results of this study are in accordance with those reported previously. ${ }^{23}$ The overtone's concept ${ }^{24}$ and Tweedy's chelation theory ${ }^{25}$ might be used to explain the enhanced in antibacterial activity of the metal complexes.

\section{Conclusion}

Using microwave assisted heating, three new zinc(II) complexes derived from the Schiff base ligand 5-bro-

Table 4. Diameter of growth of inhibition zone (mm)

\begin{tabular}{lcccc}
\hline Compounds & $\begin{array}{c}\text { Staphylococcus } \\
\text { aureus }\end{array}$ & $\begin{array}{c}\text { Bacillus } \\
\text { subtilis }\end{array}$ & $\begin{array}{c}\text { Escherichia } \\
\text { coli }\end{array}$ & $\begin{array}{c}\text { Pseudomonas } \\
\text { aeruginosa }\end{array}$ \\
\hline HL & 6.1 & 13.2 & 7.5 & 3.4 \\
$\mathbf{1}$ & 8.6 & 15.5 & 9.2 & 5.1 \\
$\mathbf{2}$ & 9.8 & 17.6 & 15.1 & 11.3 \\
$\mathbf{3}$ & 9.5 & 16.8 & 16.4 & 12.7 \\
Ciprofloxacin & 25.1 & 20.8 & 24.9 & 22.6 \\
\hline
\end{tabular}

Table 5. MIC values $(\mu \mathrm{M})$

\begin{tabular}{lcccc}
\hline Compounds & $\begin{array}{c}\text { Staphylococcus } \\
\text { aureus }\end{array}$ & $\begin{array}{c}\text { Bacillus } \\
\text { subtilis }\end{array}$ & $\begin{array}{c}\text { Escherichia } \\
\text { coli }\end{array}$ & $\begin{array}{c}\text { Pseudomonas } \\
\text { aeruginosa }\end{array}$ \\
\hline HL & 128 & 32 & 64 & 256 \\
$\mathbf{1}$ & 64 & 16 & 64 & 128 \\
$\mathbf{2}$ & 32 & 8 & 8 & 32 \\
$\mathbf{3}$ & 32 & 8 & 8 & 32 \\
Ciprofloxacin & 16 & 8 & 16 & 16 \\
\hline
\end{tabular}


mo-2-(((2-isopropylamino)ethyl)imino)methyl)phenol have been synthesized and characterized by infrared and electronic spectra, and conductance measurement. Structures of the complexes have been confirmed by single crystal X-ray determination. The complexes show interesting antibacterial activities on the bacteria Staphylococcus aureus and Escherichia coli, which deserves further study.

\section{Supplementary Materials}

The X-ray crystallographic data in the CIF format for the structures of the complexes reported in this paper have been deposited with the Cambridge Crystallographic Data Center, and the supplementary crystallographic data can be obtained free of charge on request at www.ccdc.cam. ac.uk/conts/retrieving.html [or from The Director, Cambridge Crystallographic Data Center, CCDC, 12 Union Road, Cambridge CB2 1EZ, UK; fax: +44(0)1223-336033; email: deposit@ccdc.cam.ac.uk], quoting the CCDC numbers 2061673, 2061674 and 2061675.

\section{Acknowledgments}

This project was supported by the Qiqihar University.

\section{References}

1. (a) R. T. Liu, C. L. Yuan, Y. Feng, J. Y. Qian, X. T. Huang, Q. T. Chen, S. Y. Zhou, Y. Ding, B. B. Zhai, W. J. Mei, L. Z. Yao, RSC Advances 2021, 11, 4444-4453; DOI:10.1039/D0RA09418H (b) D. L. Zhou, W.-P. To, E. N. S. M. Tong, G. Cheng, L. L. Du, D. L. E. Phillips, C. M. Che, Angew. Chem. Int. Ed. 2020, 59, 6375-6382; DOI:10.1002/anie.201914661

(c) L. R. Piquer, S. Dey, L. Castilla-Amoros, S. J. Teat, J. Cirera, G. Rajaraman, E. C. Sanudo, Dalton Trans. 2019, 48, 12440-12450; DOI:10.1039/C9DT02567G

(d) L. R. Piquer, E. C. Sanudo, Polyhedron 2019, 169, 195-

201; DOI:10.1016/j.poly.2019.05.011

(e) L. L. L. S. Melo, G. P. Castro, S. M. C. Goncalves, Inorg. Chem. 2019, 58, 3265-3270.

DOI:10.1021/acs.inorgchem.8b03340

2. (a) S.-H. Zhang, Y.-L. Zhou, X.-J. Sun, L.-Q. Wei, M.-H. Zeng, H. Liang, J. Solid State Chem. 2009, 182, 2991-2996; DOI:10.1016/j.jssc.2009.08.009

(b) S.-H. Zhang, C. Feng, J. Mol. Struct. 2010, 977, 62-66. DOI:10.1016/j.molstruc.2010.05.010

3. J. R. Anacona, M. Lorono, D. Marpa, C. Ramos, F. Celis, Appl. Organomet. Chem. 2020, 34, e5755. DOI:10.1002/aoc.5755

4. (a) X.-D. Wang, W. Wei, P.-F. Wang, L.-C. Yi, W.-K. Shi, Y.-X. Xie, L.-Z. Wu, N. Tang, L.-S. Zhu, J. Peng, C. Liu, X.-H. Li, S. Tang, Z.-P. Xiao, H.-L. Zhu, Bioorg. Med. Chem. 2015, 23, 4860-4865; DOI:10.1016/j.bmc.2015.05.026

(b) Z.-P. Xiao, W. Wei, P.-F. Wang, W.-K. Shi, N. Zhu, M.Q. Xie, Y.-W. Sun, L.-X. Li, Y.-X. Xie, L.-S. Zhu, N. Tang, H. Ouyang, X.-H. Li, G.-C. Wang, H.-L. Zhu, Eur. J. Med. Chem.
2015, 102, 631-638; DOI:10.1016/j.ejmech.2015.08.025

(c) W. Wei, W.-K. Shi, P.-F. Wang, X.-T. Zeng, P. Li, J.-R. Zhang, Q. Li, Z.-P. Tang, J. Peng, L.-Z. Wu, M.-Q. Xie, C. Liu, X.-H. Li, Y.-C. Wang, Z.-P. Xiao, H.-L. Zhu, Bioorg. Med. Chem. 2015, 23, 6602-6611; DOI:10.1016/j.bmc.2015.09.018

(d) Z.-P. Xiao, X.-D. Wang, P.-F. Wang, Y. Zhou, J.-W. Zhang, L. Zhang, J. Zhou, S.-S. Zhou, H. Ouyang, X.-Y. Lin, M. Mustapa, A. Reyinbaike, H.-L. Zhu, Eur. J. Med. Chem. 2014, 80, 92-100; DOI:10.1016/j.ejmech.2014.04.037

(e) X.-D. Wang, W. Wei, P.-F. Wang, Y.-T. Tang, R.-C. Deng, B. Li, S.-S. Zhou, J.-W. Zhang, L. Zhang, Z.-P. Xiao, H. Ouyang, H.-L. Zhu, Bioorg. Med. Chem. 2014, 22, 3620-3628;

DOI:10.1016/j.bmc.2014.05.018

(f) X.-D. Wang, W. Wei, R.-C. Deng, S.-S. Zhou, L. Zhang, X.Y. Lin, Z.-P. Xiao, Chin. J. Org. Chem. 2014, 34, 1773-1779; DOI:10.6023/cjoc201404042

(g) X.-D. Wang, R.-C. Deng, J.-J. Dong, Z.-Y. Peng, X.-M. Gao, S.-T. Li, W.-Q. Lin, C.-L. Lu, Z.-P. Xiao, H.-L. Zhu, Bioorg. Med. Chem. 2013, 21, 4914-4922.

DOI:10.1016/j.bmc.2013.06.066

5. (a) H. Kargar, Trans. Met. Chem. 2014, 39, 811-817;

DOI:10.1007/s11243-014-9863-4

(b) A. Sahraei, H. Kargar, M. Hakimi, M. N. Tahir, J. Mol. Struct. 2017, 1149, 576-584; DOI:10.1016/j.molstruc.2017.08.022

(c) A. Sahraei, H. Kargar, M. Hakimi, M. N. Tahir, Trans. Met. Chem. 2017, 42, 483-489;

DOI:10.1007/s11243-017-0152-x

(d) A. Jamshidvand, M. Sahihi, V. Mirkhani, M. Moghadam, I. Mohammadpoor-Baltork, S. Tangestaninejad, H. A. Rudbari, H. Kargar, R. Keshavarzi, S. Gharaghani, J. Mol. Liquids 2018, 253, 61-71; DOI:10.1016/j.molliq.2018.01.029

(e) H. Kargar, R. Behjatmanesh-Ardakani, V. Torabi, M. Kashani, Z. Chavoshpour-Natanzi, Z. Kazemi, V. Mirkhani, A. Sahraei, M. N. Tahir, M. Ashfaq, K. S. Munawar, Polyhedron 2021, 195, 114988; DOI:10.1016/j.poly.2020.114988

(f) H. Kargar, F. Aghaei-Meybodi, R. Behjatmanesh-Ardakani, M. R. Elahifard, V. Torabi, M. Fallah-Mehrjardi, M. N. Tahir, M. Ashfaq, K. S. Munawar, J. Mol. Struct. 2021, 1230, 129908; DOI:10.1016/j.molstruc.2021.129908

(g) H. Kargar, A. A. Ardakani, M. N. Tahir, M. Ashfaq, K. S. Munawar, J. Mol. Struct. 2021, 1233, 130112.

DOI:10.1016/j.molstruc.2021.130112

6. (a) N. Farahani, M. Khalaj, J. Mol. Struct. 2021, 1228, 129747; DOI:10.1016/j.molstruc.2020.129747

(b) Y.-L. Sang, X.-S. Lin, W.-D. Sun, Acta Chim. Slov. 2020, 67, 581-585; DOI:10.17344/acsi.2019.5595

(c) F.-M. Wang, L.-J. Li, G.-W. Zang, T.-T. Deng, Z.-L. You, Acta Chim. Slov. 2020, 67, 1155-1162;

DOI:10.17344/acsi.2020.6056

(d) H. Kargar, R. Behjatmanesh-Ardakani, V. Torabi, M. Kashani, Z. Chavoshpour-Natanzi, Z. Kazemi, V. Mirkhani, A. Sahraei, M. N. Tahir, M. Ashfaq, K. S. Munawar, Polyhedron 2021, 195, 114988; DOI:10.1016/j.poly.2020.114988 (e) N. S. Rukk, L. G. Kuzmina, R. S. Shamsiev, G. A. Davydova, E. A. Mironova, A. M. Ermakov, G. A. Buzanov, A. Y. Skryabina, A. N. Streletskii, G. A. Vorobeva, V. M. Retivov, P. 
A. Volkov, S. K. Belus, E. I. Kozhukhova, V. N. Krasnoperova, Inorg. Chim. Acta 2019, 487, 184-200.

DOI:10.1016/j.ica.2018.11.036

7. Siemens, SAINT: Area Detector Control and Integration Software, Siemens Analytical X-ray Instruments Inc., Madison, WI, USA, 1996.

8. G. M. Sheldrick, SHELXL97 and SHELXTL Software Reference Manual, Version 5.1, Brucker AXS Inc., Madison, WI, USA, 1997.

9. G. M. Sheldrick, SADABS, University of Göttingen, Germany, 1996.

10. M. N. Burnett, C. K. Jonnson, ORTEP III, Report ORNL6895, Oak Ridge National Laboratory, Tennessee, USA, 1996.

11. K. Singh, Y. Kumar, P. Puri, C. Sharma, K. R. Aneja, Med. Chem. Res. 2012, 21, 1708-1716.

DOI:10.1007/s00044-011-9683-4

12. M. I. Okeke, C. U. Iroegbu, E. N. Eze, A. S. Okoli, C. O. Esimone, J. Ethnopharmacol. 2001, 78, 119-127.

DOI:10.1016/S0378-8741(01)00307-5

13. W. J. Geary, Coord. Chem. Rev. 1971, 7, 81-122.

DOI:10.1016/S0010-8545(00)80009-0

14. G. Kastas, C. A. Kastas, A. Tabak, Spectrochim. Acta A 2019, 222, 117198. DOI:10.1016/j.saa.2019.117198

15. U. Kumar, J. Thomas, N. Thirupathi, Inorg. Chem. 2010, 49, 62-72. DOI:10.1021/ic901100z
16. S. Daravath, A. Rambabu, N. Vamsikrishna, N. Ganji, S. Raj, J. Coord. Chem. 2019, 72, 1973-1993. DOI:10.1080/00958972.2019.1634263

17. A. A. El-Sherif, A. Fetoh, Y. K. Abdulhamed, G. M. Abu ElReash, Inorg. Chim. Acta 2018, 480, 1-15.

DOI:10.1016/j.ica.2018.04.038

18. A. Jayamani, M. Sethupathi, S. O. Ojwach, N. Sengottuvelan, Inorg. Chem. Commun. 2017, 84, 144-149.

DOI:10.1016/j.inoche.2017.08.013

19. S. Shit, P. Talukder, J. Chakraborty, G. Pilet, M. S. El Fallah, J. Ribas, S. Mitra, Polyhedron 2007, 26, 1357-1363.

DOI:10.1016/j.poly.2006.11.013

20. A. W. Addison, T. N. Rao, J. Reedijk, J. van Rijn, G. C. Verschoor, J. Chem. Soc. Dalton Trans. 1984, 7, 1349-1356. DOI:10.1039/DT9840001349

21. Y. Luo, J. Wang, X. Ding, R. Ni, M. Li, T. Yang, J. Wang, C. Jing, Z. You, Inorg. Chim. Acta 2021, 516, 120146. DOI:10.1016/j.ica.2020.120146

22. A. Guha, T. Chattopadhyay, N. D. Paul, M. Mukherjee, S. Goswami, T. K. Mondal, E. Zangrando, D. Das, Inorg. Chem. 2012, 51, 8750-8759. DOI:10.1021/ic300400v

23. K. Singh, Y. Kumar, P. Puri, M. Kumar, C. Sharma, Eur. J. Med. Chem. 2012, 52, 313-321. DOI:10.1016/j.ejmech.2012.02.053

24. N. Raman, A. Kulandaisamy, K. Jayasubramanian, Polish J. Chem. 2002, 76, 1085-1094.

25. B. G. Tweedy, Phytopathology 1964, 55, 910-915.

\section{Povzetek}

$\mathrm{Z}$ mikrovalovnim obsevanjem smo sintetizirali tri nove cinkove komplekse: $\left[\mathrm{Zn}_{3} \mathrm{~L}_{2}\left(\mu_{2}-\eta^{1}: \eta^{1}-\mathrm{CH}_{3} \mathrm{COO}\right)_{2}\left(\mu_{2}-\eta^{2}: \eta^{0}-\right.\right.$ $\left.\left.\mathrm{CH}_{3} \mathrm{COO}\right)_{2}\right](1),\left[\mathrm{ZnCl}_{2}(\mathrm{HL})\right](2)$ in $\left[\mathrm{ZnBr}_{2}(\mathrm{HL})\right](3)$, pri čemer je $\mathrm{L}=$ 5-bromo-2-(((2-izopropilamino)etil)imino)metil) fenolat, $\mathrm{HL}=5$-bromo-2-((2-izopropilamonijev)etil)imino)metil)fenolat. Produkte smo karakterizirali $\mathrm{z}$ elementno analizo, IR, UV-Vis spektri, meritvami molske prevodnosti in monokristalno rentgensko difrakcijo. Strukturna analiza je pokazala, da so cinkovi atomi v spojini 1 kvadratno - piramidalno in oktaedrično koordinirani, medtem ko so v spojinah 2 in 3 tetraedrično koordinirani. Molekule $\mathrm{v}$ kompleksih so povezane $\mathrm{z}$ vodikovimi vezmi in $\pi \cdots \pi$ interakcijami. Biološko aktivnost produktov smo preverili $\mathrm{z}$ in vitro antibakterijskim delovanjem na bakterije Staphylococcus aureus, Bacillus subtilis, Escherichia coli in Pseudomonas aeruginosa.

Except when otherwise noted, articles in this journal are published under the terms and conditions of the Creative Commons Attribution 4.0 International License 